\title{
The assessment of influence of soil erosion by water in the transformation of agricultural slopes of the Wiśnicz Foothills
}

\author{
Jolanta Święchowicz \\ Instytut of Geography and Spatial Management, Jagiellonian University in Kraków, Poland, jolanta.swiechowicz@uj.edu.pl
}

\begin{abstract}
The main aim of the paper is to assess influence of soil erosion by water in the transformation of agricultural slopes of the edge of Wiśnicz Foothills. Low hills are typical in the morphology of the area. Results presented come from measurements of soil erosion by water in 2007-2009. Soil erosion took place during short transformation periods and was caused by events of high magnitude and low frequency during which soil particles are transported from the slope to the channel, but its supply was only local and episodic. In the foothill area slope and channel are weakly linked.
\end{abstract}

Key words: soil erosion by water, raindrop erosion, slopewash, linear erosion, Wiśnicz Foothills, Poland

\section{Introduction}

Agricultural slopes, which are devoid of natural vegetation cover react very quickly to any changes in the environment and are one of the most dynamically developing relief forms (Gerlach 1976a, Teisseyre 1994, Rodzik et al. 1998, Rodzik 2001, Rejman, Usowicz 2002, Stankoviansky 2002, Zgłobicki 2002, Smolska 2005, 2010, Cerda et al. 2007, Cerda 2009, 2011, Święchowicz 2008a, b, 2010a, 2017, Novara et al. 2011, Janicki 2016).

Soil erosion by water, which causes the reduction of the thickness of soil layer leading at times to its complete removal (Józefaciuk, Józefaciuk 1995, Rejman 2006, Święchowicz 2016). Erosion not only causes permanent impoverishment of soil and the reduction of crop yield, but also makes farming difficult, and sometimes it permanently damages large land areas (Clark et al. 1985, Auzet et al. 1990, Boardman 1995, Święchowicz 2009). In agricultural areas soil erosion by water consists in transport of very small particeles of top soil (Gerlach 1976a, Rejman et al. 1994, Gil 1999, Szpikowski 2001, 2010, Szewrański 2009, Jadczyszyn 2010, Święchowicz 2012a). In most cases, the process is hardly noticeable and transport usually happens within short distances (Rejman et al. 1990, Rejman, Brodowski
2005, Rejman 2006, Smolska 2010, Święchowicz 2010b, 2012a).

The amount of soil eroded depends on soil erodibility, rainfall erosivity, field topography, vegetation cover and tillage practice (Reniger 1950, 1955, Święchowicz 2002a, b, 2012a, b, 2016, 2017, Smolska 2003, 2008, Rejman 2006, Garcia-Ruiz 2010, Rejman, Brodowski 2010, Stępniewski et al. 2010). On cultivated foothill slopes soil erosion by water leads to a distinct transformation of foothill slopes and causes damage to agriculture (Lach 1985, Święchowicz 2009). The process of intensified water erosion is more significant on commercial farms with a large acreage of crops (Święchowicz 2008a, b).

Soil erosion is the most intensive as a result of local downpours, continuous rains and wet years (Olecki 1970, Kostrzewski et al. 1989, 1992, Janicki, Zgłobicki 1998, Rodzik, Janicki 2003, Janicki 2007, Długosz, Gębica 2008, Święchowicz 2008a, 2012a, Gil 2009, Janicki et al. 2010, Majewski 2014). The influence of soil erosion by water consist on the formation of new forms and the transformation of existinng ones (Rejman, Rodzik 2006, Święchowicz 2012a). Changes include shape and length of the slopes: decrease inclination, extending the footslope area, creating footslope plains, extending the bottom of the valleys (Teisseyre 1994, Długosz, Gębica 
2008, Święchowicz 2012a, Janicki 2016). Soil erosion by water also creates new forms: rills, ephemeral channels, ephemeral gullies, gullies (Teisseyre 1994, Święchowicz 2008a, 2010b, 2012a, 2017, Janicki 2016).

Soil erosion rarely happens on all the slopes in a catchment simultaneously and its intensity is differentiated along the longitudinal profile of the slope (Gerlach 1966, Święchowicz 2012a). The aim of this paper is to assess influence of soil erosion by water in the transformation of agricultural slopes of the edge of Wiśnicz Foothills (Brzesko Foreland).

\section{Study area}

Research was carried out in the lowest marginal zone of the Carpathian Foothills, where the Field Research Station of the Institute of Geography of the Jagiellonian University is located (Fig. 1). In the foothill zone, the dominant relief type is low hills, convex-concave slopes, flat and broad valley bottoms which separate slopes and stream channels. The thickness of slope cover amounts to $20 \mathrm{~m}$. There are also loess patches, several to a dozen meters thick that may potentially contribute to severe erosion. Stationary measurement of soil erosion by water was conducted on plots in Dworski Potok catchment located in the village of Łazy, in the lowest marginal zone of the Carpathian Foothills (Brzesko Foreland).

It covers the area of $0.29 \mathrm{~km}^{2}$, the ranges of altitude being being 227-278 $\mathrm{m}$ a.s.l. The dominant lithology in the area consists of flysch series belonging to the sub-Silesian overthrust (Bochnia unit), and Miocene clays and sandstones, which are covered with Quaternary loess-like formations. The soil cover is weakly differentiated with Stagnic $\mathrm{Lu}$ visols (Klimek 1995). The dominant relief type are low hills. The Dworski Potok valley bottom varies in width from $5 \mathrm{~m}$ in its upper part to $50 \mathrm{~m}$ in its lower part and is incised by a channel, which is $0.5 \mathrm{~m}$ deep. The Dworski Potok valley bottom is separated from slopes by a clear edge that has been formed as a result of farming. Its height is $1-8 \mathrm{~m}$ above the valley bottom (Święchowicz, Michno 2005). Above the edge, at the foot of slope, there is a footslope deluvial flattening, $10 \mathrm{~m}$ wide (Fig. 2). The slopes in the catchment are convex-concave and their inclinations are $2-10^{\circ}$.

\section{Methods}

\section{Precipitation data}

The meteorological station is located on a drainage divide in the Dworski Potok catchment at an elevation of $245 \mathrm{~m}\left(49^{\circ} 57^{\prime} 55^{\prime \prime} \mathrm{N}, 20^{\circ} 29^{\prime} 43^{\prime \prime} \mathrm{E}\right.$ ) (Fig. 2). The obtained data are representative for mountain tops and upper parts of slopes of low foothills. Data were collected at Lazy Field Research Station in hydrological years 1987-2009.

In this study, a single erosive rainfall is defined as a rainfall with a minimum of $12.7 \mathrm{~mm}$ of precipitation and it comes after a period of 6 hours without rain or with rainfall depth lower than $1.3 \mathrm{~mm}$ (Święchowicz 2010a, 2012a). The formula was calculated on the basis on hyetograph records, kinetic energy of rainfall

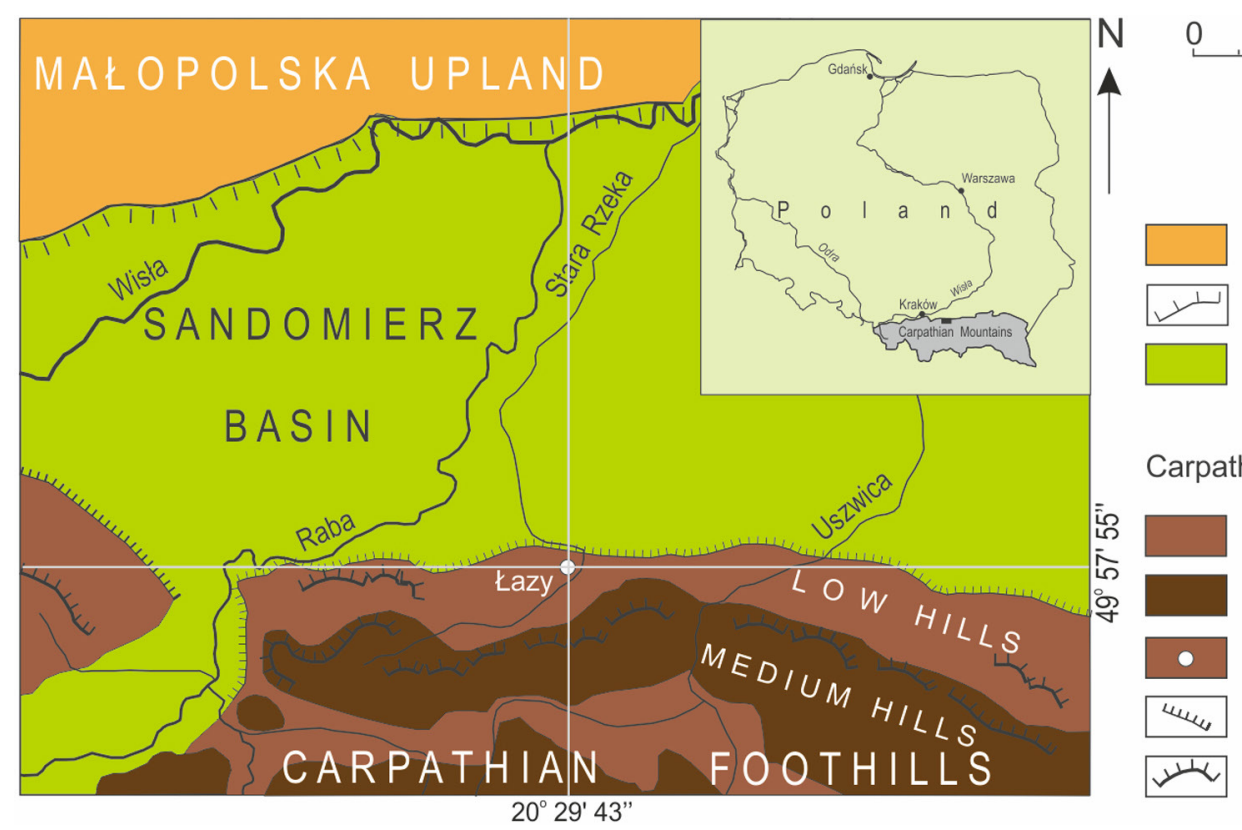

Małopolska Upland

Małopolska Upland escarpment

Sandomierz Basin

Carpathian Foothills

low hills

medium hills

study area

low hills escarpment

medium hills escarpment

Fig. 1. Location of study area 

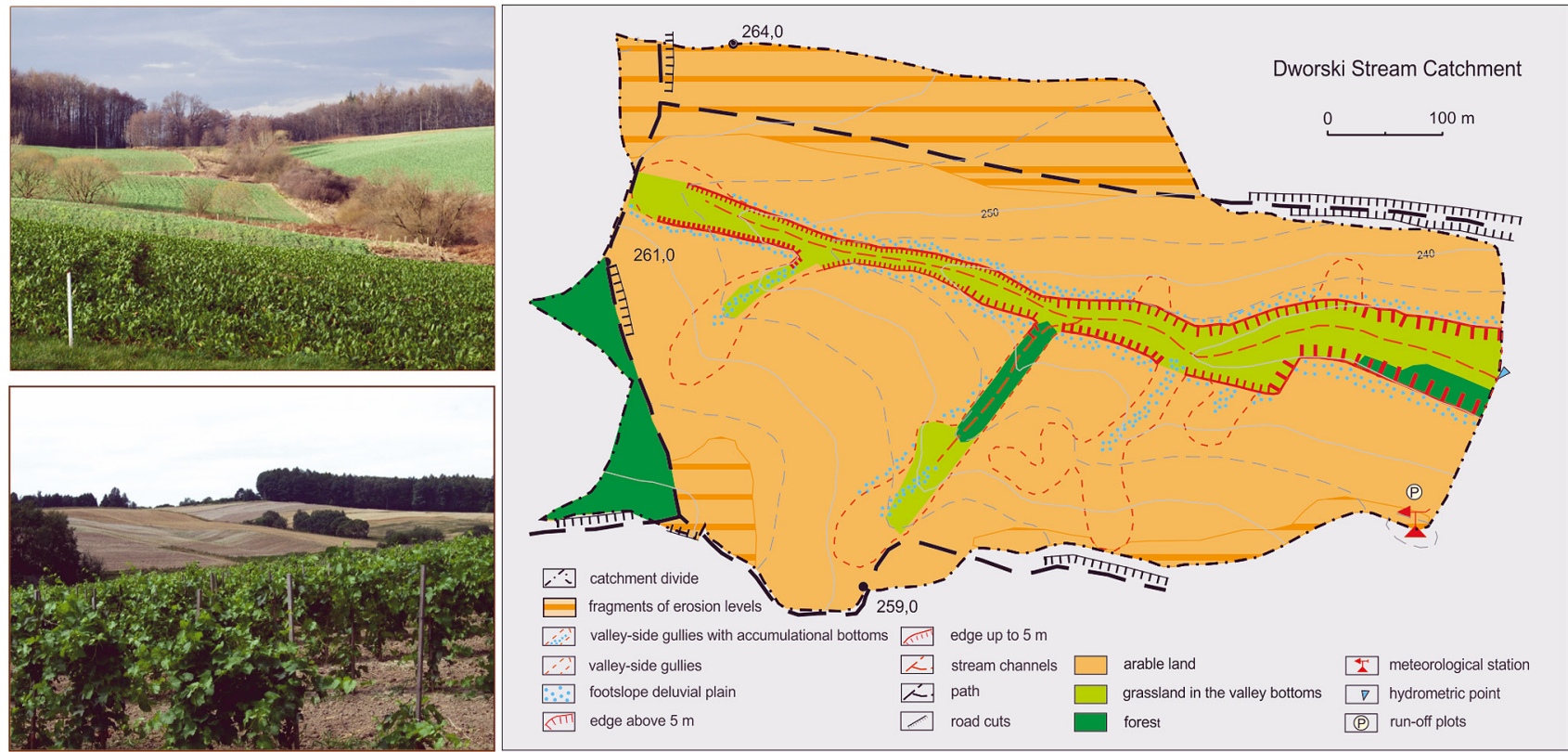

Fig. 2. Relief and land use of Dworski Stream catchment

according to Brown and Foster (1987). For each potentially erosive rainfall, average intensity, maximum 30-minute $\left[I_{30}\right]$ intensity and single rainfall erosivity $\left[E I_{30}\right]$ were calculated according to the following formula (Wischmeier, Smith 1978):

$$
E I_{30}=E_{\text {kin }} I_{30}
$$

where:

- $E I_{30}$ - single rainfall erosivity $\left(\mathrm{MJ} \mathrm{mm} \mathrm{ha-1} \mathrm{h}^{-1}\right)$,

- $E_{k i n}-$ kinetic energy of the whole rainfall event,

- $I_{30}$ - the maximum 30-minute rainfall intensity during the storm $\left(\mathrm{mm} \mathrm{h}^{-1}\right)$.

\section{Raindrop erosion}

The measurement of splash erosion was obtained during the summer months in the period 2007-2009 on a small ploughed plot but one not used for agricultural purposes (Fig. 3). Twenty eight plastic funnels of varying diameter were used, four times each. (Święchowicz 2012a). Measurements were taken following every rainfall event. The amount of splash is proportional to the diameter of a funnel; however, it decreases when calculated in relation to the funnel surface. The application of funnels of different diameters made it possible to calibrate splash data using a splashing model created by Van Dijk et al. (2002).

\section{Slopewash}

Results presented in the paper come from measurements of soil erosion by water on four runoff plots in 2007-2009 hydrological year. The plots were located on a convex-concave slope facing north, $\sim 50 \mathrm{~m}$ from a catchment divide. The meteorological station that collected the precipitation data used in this paper is located close to this plot. All the plots were 2 $\mathrm{m}$ wide and were $22.1 \mathrm{~m}$ long. The slope steepness of the plots was $8^{\circ}$. The plots were protected using plastic foiland closed off with a 2-m Gerlach gutter, which catches water and material eroded from each plot and then sends them to a separate water tank with a limnigraph. After each rainfall, measurements of surface flow and soil erosion were taken. Measurements were performed following each precipitation event characterized by effective erosion (Święchowicz 2012a, 2017).
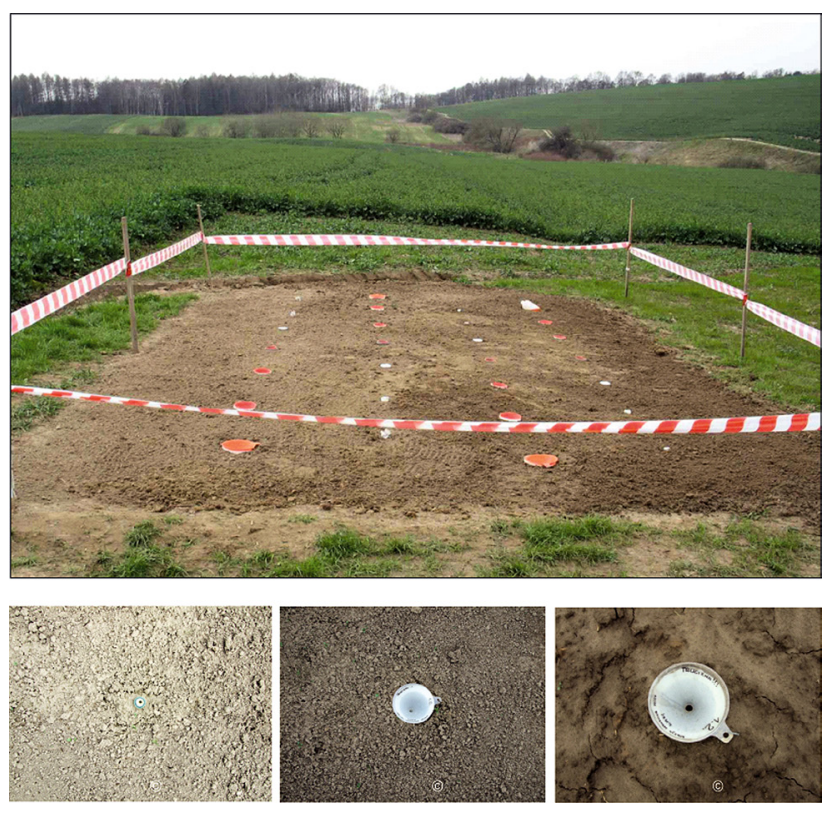

Fig. 3. Splash plot in hydrological years 2007-2009 

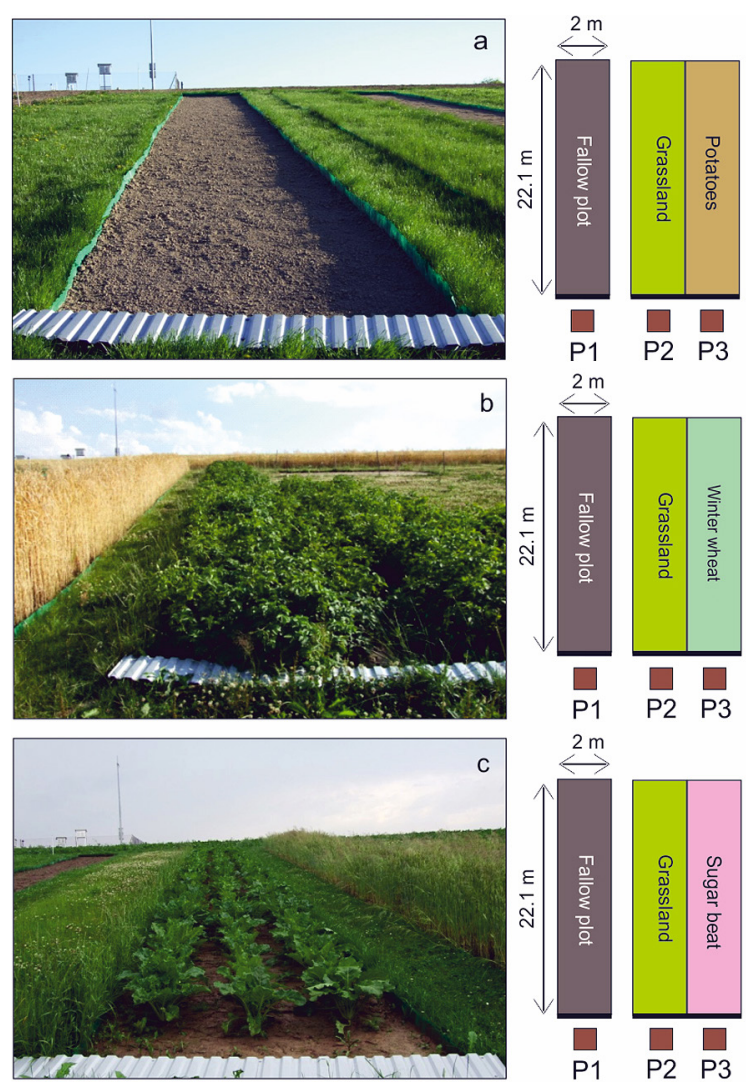

Fig 4. Land use pattern on run-off plots in hydrological years 2007-2009

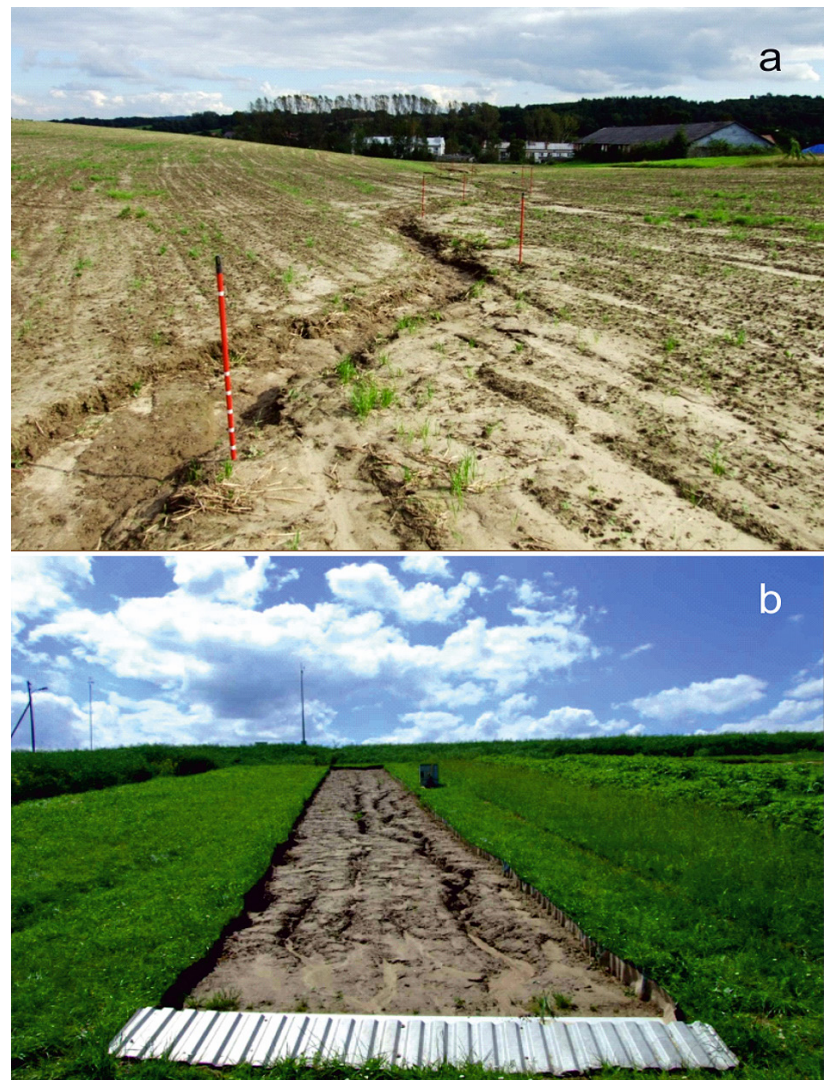

Fig. 5. Linear erosion along natural drainage line (a) and on run-off plot (b)
In 2007 out of the four plots - one was fallow plot, one was grassland, one was a potato field and the remaining one had winter wheat (Fig. 4a). In 2008 out of the four plots - one was fallow plot, one was grassland and one was winter wheat whereas the remaining four were potato field (Fig. 4b). In 2009 out of the four plots - one was fallow plot, one was grassland, one was sugarbeet field and last one had winter wheat crops (Fig. 4c).

\section{Linear erosion}

Rill depths were measured immediately following rainfall events at selected cross sections in the study area (Fig. 5, Święchowicz 2008a, 2011, 2012a). Distances between consecutive cross sections were also measured. The surface of each profile was calculated, which was then multiplied by the length of a section to give the total volume of rills on the plot. The mass of eroded soil was calculated using the following equation:

$$
E=V D_{b}
$$

where:

- E- estimated rill erosion $[\mathrm{Mg}]$,

- $V$-volume of soil loss $\left[\mathrm{m}^{3}\right]$,

- $D_{b}$ - dry bulk density $\left[\mathrm{Mg} \mathrm{m}^{-3}\right]$.

\section{Results}

Mean annual precipitation from 1987 to 2009 amounted to $665.9 \mathrm{~mm}$. Annual precipitation totals varied from 442.1 (2003) to $814.1 \mathrm{~mm}$ (2007) (Święchowicz 2012a, Fig. 6).

The most precipitation took place in the summer half-year (V-X) and it constituted from 55.4\% (1998) to $78.6 \%$ (1997) of the annual precipitation total. On average, in hydrological years 1987-2009 there were 168 days with precipitation. Dominant were days

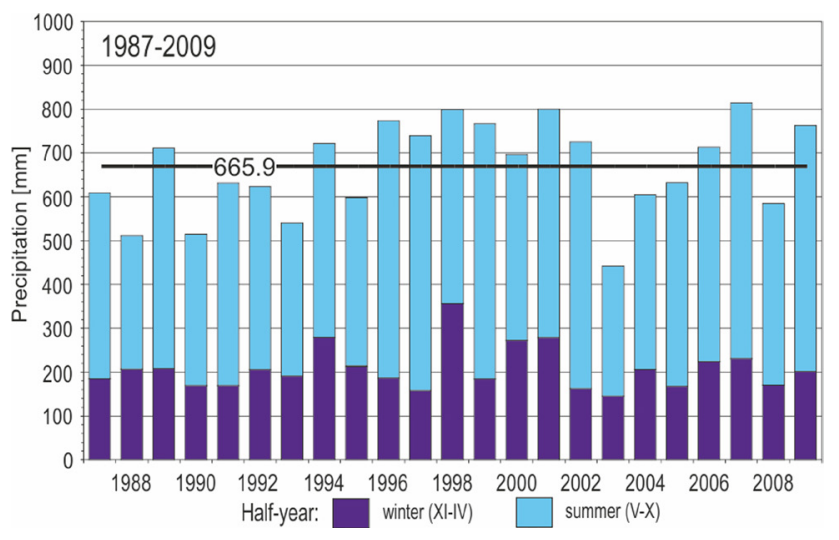

Fig. 6. Annual totals of precipitation in 1987-2009 
Table 1. Rainfall characteristic (Łazy near Bochnia, 20072009)

\begin{tabular}{|c|c|c|c|c|}
\hline \multicolumn{2}{|c|}{ Parameter } & 2007 & 2008 & 2009 \\
\hline \multirow{2}{*}{\multicolumn{2}{|c|}{ 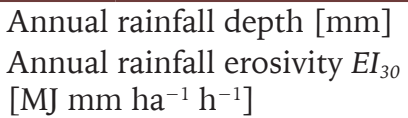 }} & 814.1 & 585.3 & 763.0 \\
\hline & & $1,628.9$ & 667.0 & $2,377.8$ \\
\hline \multirow{13}{*}{ 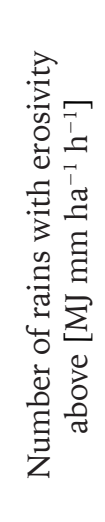 } & 50 & 6 & 2 & 6 \\
\hline & 100 & 6 & - & 3 \\
\hline & 150 & 4 & - & 3 \\
\hline & 200 & 2 & - & 2 \\
\hline & 250 & - & - & 2 \\
\hline & 300 & - & - & 2 \\
\hline & 400 & - & - & 2 \\
\hline & 500 & - & - & 2 \\
\hline & 600 & - & - & 1 \\
\hline & 700 & - & - & 1 \\
\hline & 800 & - & - & 1 \\
\hline & 900 & - & - & 1 \\
\hline & 1000 & - & - & 0 \\
\hline
\end{tabular}

with very weak $(0.1-1.0 \mathrm{~mm})$ and weak $(1.1-5.0 \mathrm{~mm})$ precipitation and they constituted $62.9 \%$ of all the days with precipitation in the summer half-year. Days with strong and very strong precipitation (above 20 $\mathrm{mm}$ ) constituted only $7.2 \%$ of all the days with precipitation and occurred mainly in the summer halfyear. Maximum daily precipitation $(83.4 \mathrm{~mm})$ was in in June in 2006.

The hydrological year 2007 was wet with annual precipitation total $814.1 \mathrm{~mm}$, the 2008 was dry with annual precipitation total of $585.3 \mathrm{~mm}$ and ther 2009 was wet with annual precipitation total of $763 \mathrm{~mm}$ (Fig. 6).

In 2007, with the highest annual rainfall erosivity $E I_{30}$ index was $1,628.9 \mathrm{MJ} \mathrm{mm} \mathrm{ha}{ }^{-1} \mathrm{~h}^{-1}$ and was nearly 2.4 times higher than in the dry year 2008 (667 MJ $\mathrm{mm} \mathrm{ha}^{-1} \mathrm{~h}^{-1}$ ). In 2009, the $E I_{30}$ was exceptionally high and amounted to $2,377.8 \mathrm{MJ} \mathrm{mm} \mathrm{ha}^{-1} \mathrm{~h}^{-1}$, even though the annual the sum of rainfall was $51.1 \mathrm{~mm}$ lower than in 2007. However, the $E I_{30}$ index was 3.6 times higher than in the dry year. These differences were caused by the occurrence of several in 2007 precipitation with erosivity in the range of $100-250 \mathrm{MJ} \mathrm{mm} \mathrm{ha}^{-1} \mathrm{~h}^{-1}$, very low erosivity in 2008 and the occurrence of 2 precipitation with a record erosion in 2009 (Tab. 1).

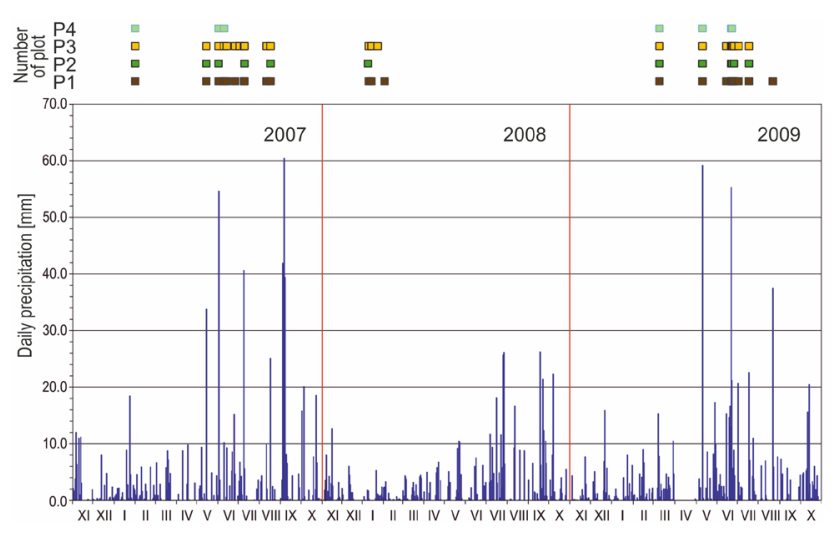

Fig. 7. Number of slope wash events in relation to daily totals of precipitation in hydrological years 2007-2009 P1 - fallow plot, P2 - grassland, P3 - potatoes in 2007 and suger beet in 2009, P4 - winter wheat; dimension of all plots: $22.1 \times 2 \mathrm{~m}$

In the wet 2007 hydrological year in the summer half-year there were 21 rain events, in the dry 2008 hydrological year -28 and in wet $2009-25$. Each of them might have been a potential source of erosion. However, only 13 (2007), and 9 (2009) events of soil erosion were observed in the wet hydrological years in the summer half-year whereas in the dry 2008 hydrological year not a single soil wash event was observed (Fig. 7). The majority of events in 2007 and 2009 hydrological years occurred in summer (June, July, and August) and autumn (September). Slope wash events took place mainly during heavy and very heavy rains, although there were single events caused by moderate rains. The number of slope wash events on plots of the same length differed in relation to their agricultural use. Slope wash did not occur simultaneously on all the plots during the same rainfalls. In 2007 and 2009 hydrological years, rain events with daily totals of precipitation above $20 \mathrm{~mm}$ always resulted in overland flow and slope wash. However, in 2008 hydrological year in the summer half-year, there were 28 single rains but none of them did not cause runoff or soil erosion on the slope (Fig. 7).

In the hydrological years 2007-2009, it was found from May to October a total of 153 splash events; most of them were in June and July, and the least in August (Tab. 2).

Table 2. Number of splash events on a bare fallow plot in summer half-year (Łazy near Bochnia, 2007-2009)

\begin{tabular}{lccccccc}
\hline \multirow{2}{*}{ Month } & \multicolumn{7}{c}{ Number of event } \\
\cline { 2 - 7 } & 2007 & 2008 & 2009 & Sum & Average & S.D. & C.V. \\
\hline May & 5 & 8 & 11 & 24 & 8.0 & 3.0 & 37.5 \\
June & 8 & 8 & 15 & 31 & 10.3 & 4.0 & 39.1 \\
July & 8 & 14 & 9 & 31 & 10.3 & 3.2 & 31.1 \\
August & 8 & 5 & 5 & 18 & 6.0 & 1.7 & 28.9 \\
September & 10 & 10 & 6 & 26 & 8.7 & 2.3 & 26.6 \\
October & 8 & 5 & 12 & 25 & 8.3 & 3.5 & 42.1 \\
Sum & 47 & 50 & 58 & 155 & 51.7 & 5.7 & 11.0 \\
\hline
\end{tabular}


Table 3. Rainfall parameters, splash, soil resistance to splash and splash travel distance based on van Dijk et al. (2002a) model in summer half-year (Łazy near Bochnia, 2007-2009)

\begin{tabular}{cccccc}
\hline Year & $\begin{array}{c}\text { Depth of rainfall } \\
{[\mathrm{mm}]}\end{array}$ & $\begin{array}{c}\text { Kinetic energy } \\
{\left[\mathrm{J} \mathrm{m}^{-2}\right]}\end{array}$ & $\begin{array}{c}\text { Splash } \\
{\left[\mathrm{kg} \mathrm{m}^{-2}\right]}\end{array}$ & $\begin{array}{c}\text { Resistance of soil to splash } \\
{\left[\mathrm{J} \mathrm{kg}^{-1}\right]}\end{array}$ & $\begin{array}{c}\text { Splash travel distance } \\
{[\mathrm{cm}]}\end{array}$ \\
\hline 2007 & 583.2 & $8,377.6$ & 6.650 & $1,259.8$ & $2-48$ \\
2008 & 415.3 & $5,164.1$ & 2.833 & $1,822.8$ & $2-30$ \\
2009 & 561.4 & $8,486.6$ & 4.142 & $2,048.8$ & $2-22$ \\
\hline
\end{tabular}

Table 4. Slope wash $\left[\mathrm{kg} \mathrm{ha}^{-1}\right]$ on $22.1 \mathrm{~m}$ long run-off plots in 2007-2009 year (Łazy near Bochnia)

\begin{tabular}{|c|c|c|c|c|c|}
\hline \multirow{2}{*}{ Year } & \multirow{2}{*}{ Month } & \multicolumn{4}{|c|}{ Solil erosion by water } \\
\hline & & fallow plot & grassland & potatoes $^{1}$, sugar beet ${ }^{2}$ & winter weat \\
\hline \multirow{16}{*}{2007} & $\mathrm{XI}$ & & & & \\
\hline & XI & & & & \\
\hline & XII & & & & \\
\hline & I & 0.5 & 0.2 & 0.4 & $\mathrm{n}$ \\
\hline & II & & & & \\
\hline & III & & & & \\
\hline & IV & & & & \\
\hline & $\mathrm{V}$ & 417.2 & 14.4 & $1,731.4$ & $\mathrm{n}$ \\
\hline & VI & $20,438.4$ & 9.7 & $17,817.2$ & 24.2 \\
\hline & VII & $19,617.6$ & 15.9 & $16,304.7$ & 2.6 \\
\hline & VIII & $4,877.2$ & 1.0 & $3,183.5$ & $\mathrm{n}$ \\
\hline & IX & $1,989.3$ & 0.8 & $4,358.7$ & 3.8 \\
\hline & $\mathrm{X}$ & & & & \\
\hline & XI-IV & 0.5 & 0.2 & 0.4 & $\mathrm{n}$ \\
\hline & $\mathrm{V}-\mathrm{X}$ & $47,339.7$ & 41.7 & $43,395.6$ & $\mathrm{n}$ \\
\hline & $\mathrm{XI}-\mathrm{X}$ & $47,340.2$ & 41.9 & $43,396.0$ & 31.4 \\
\hline \multirow[t]{15}{*}{2008} & $\mathrm{XI}$ & & & & \\
\hline & XII & & & & \\
\hline & I & 2.9 & 2.3 & & 8.0 \\
\hline & II & & & & \\
\hline & III & & & & \\
\hline & IV & & & & \\
\hline & $\mathrm{V}$ & & & & \\
\hline & VI & & & & \\
\hline & VII & & & & \\
\hline & VIII & & & & \\
\hline & IX & & & & \\
\hline & $\mathrm{X}$ & & & & \\
\hline & XI-IV & 2.9 & 2.3 & & 8.0 \\
\hline & $\mathrm{V}-\mathrm{X}$ & & & & \\
\hline & XI-X & 2.9 & 2.3 & & 8.0 \\
\hline \multirow[t]{15}{*}{2009} & $\mathrm{XI}$ & & & & \\
\hline & XII & & & & \\
\hline & I & & & & \\
\hline & II & & & & \\
\hline & III & 0.6 & $\mathrm{n}$ & $\mathrm{n}$ & 0.1 \\
\hline & IV & & & & \\
\hline & $\mathrm{V}$ & $96,438.5$ & 1.6 & $16,094.4$ & 23.8 \\
\hline & VI & $68,481.4$ & 34.1 & $6,287.3$ & 127.5 \\
\hline & VII & $6,585.0$ & 0.1 & 82.0 & 0.1 \\
\hline & VIII & $\mathrm{n}$ & & & \\
\hline & IX & & & & \\
\hline & $\mathrm{X}$ & & & & \\
\hline & XI-IV & 0.6 & $\mathrm{n}$ & $\mathrm{n}$ & 0.1 \\
\hline & $\mathrm{V}-\mathrm{X}$ & $171,505.0$ & 35.8 & $22,463.7$ & 151.3 \\
\hline & $\mathrm{XI}-\mathrm{X}$ & $171,505.6$ & 35.8 & $22,463.7$ & 151.4 \\
\hline
\end{tabular}

${ }^{1}-2007,{ }^{2}-2009, \mathrm{n}-$ negligible. 
The values of splash determined according to the model van Dijka et al. (2002) were varied and amounted to $6.650 \mathrm{~kg} \mathrm{~m}^{-2}$ in $2007,2.833 \mathrm{~kg} \mathrm{~m}^{-2}$ in 2008 and $4.142 \mathrm{~kg} \mathrm{~m}^{-2}$ in 2009. A great difference in the mass of the soil particles were in 2007 and 2009. In those years, the kinetic energy of rain it was similar, and the size of the splash differed more than 1.5 times (Tab. 3). Resistance soil for splashing, understood as the amount of energy needed to detach $1 \mathrm{~kg}$ of material soil, ranged from 1,259.8 to $2,048.8$ $\mathrm{J} \mathrm{kg}^{-1}$. The greatest resistance of the soil to splash was observed in 2009, in which relatively high kinetic energy of precipitation has been found but relatively small soil splash. Distances of soil movement determined from the van Dijk et al. (2002) model contained from 2 to $48 \mathrm{~cm}$, and the largest the differences were characterized in 2007 (Tab. 3). In the hydrological summer of 2007, the mass of soil particles transported during individual rain events ranged from 0.002 to $1.031 \mathrm{~kg} \mathrm{~m}^{-2}$, and the total value of the splash $6.650 \mathrm{~kg} \mathrm{~m}^{-2}$. Calculated on a layer of total precipitation in the summer half-year, size unit spatter was $0.012 \mathrm{~kg} \mathrm{~m}^{-2} \mathrm{~mm}^{-1}$. The highest intensity of the proces it was in June and the smallest in October. In the summer hydrological year of 2008. The removal of soil particles during single rain events ranged from 0.001 to $0.485 \mathrm{~kg} \mathrm{~m}^{-2}$, and the total volume of soil displacement $2.833 \mathrm{~kg} \mathrm{~m}^{-2}$. Splash in conversion on the rainfall layer was $0.007 \mathrm{~kg} \mathrm{~m}^{-2} \mathrm{~mm}^{-1}$. Most soil particles were moved in July, and least in October. In 2009, splash during single rain events varied from 0.0005 to $1.987 \mathrm{~kg} \mathrm{~m}^{-2}$. Cumulative value was 4.142 and calculated as rain layer $0.007 \mathrm{~kg} \mathrm{~m}^{-2} \mathrm{~mm}^{-1}$. The largest displacement the soil was in May and the smallest in September.

In the 2007, the highest sediment loss occurred on the fallow plot. Soil erosion on the potato plot was by $8.3 \%$ lower than in the fallow plot. Erosion on winter wheat plots was low and $25 \%$ lower than on grass plots. $31.4 \mathrm{~kg} \mathrm{ha}^{-1}$ in winter wheat, $41.9 \mathrm{~kg} \mathrm{ha}^{-1}$ on meadow, $43,396.0 \mathrm{~kg} \mathrm{ha}^{-1}$ on potatoes, and fallow plot $-47,340.2 \mathrm{~kg} \mathrm{ha}^{-1}$ (Tab. 4). The ratio of soil erosion was 1:1.3:1,350.2:1,507.7 respectively. For all crops close to $100 \%$ of the soil is washed away in the summer hydrological half. The most dynamic process was in the summer months (June, July, August) and autumn (September). Only on the meadow, a high share of soil drainage was observed during the summer-spring period.

In the hydrological year 2009 the highest values of soil erosion occurred on fallow plot. The sediment loss on the sugar beet plot was more than 7.5 times smaller than in the fallow plots. Soil loss on a winter wheat plot was small and almost four times higher than on a grass-covered plot. Annual soil erosion in 2009 on plots was $35.8 \mathrm{~kg} \mathrm{ha}^{-1}$ on grass, $151.4 \mathrm{~kg} \mathrm{ha}^{-1}$ on winter wheat, $22,463.7 \mathrm{~kg} \mathrm{ha}^{-1}$ on sugar beet and
171,505.6 $\mathrm{kg} \mathrm{ha}^{-1}$ on fallow plot (Tab. 4). Nearly $100 \%$ of the soil was washed away in the summer half-year (Fig. 6). The most dynamic process was in the summer months (June, July, August) and autumn (September). Only on the meadow a large part of the soil was drained during spring and summer. The soil loss ratio was 1:4.2:627.9:4,793.8 respectively.

The strong soil erosion by water on the slopes took place on 17th June 2006, during daily rainfall of the amount of $83.4 \mathrm{~mm}$, which lasted only 85 (Święchowicz 2009, 2012, 2017; Fig. 8). The downpour lasted from $15.45 \mathrm{pm}$ to $17.10 \mathrm{pm}$ producing $82.6 \mathrm{~mm}$ of precipitation. Mean intensity amounted to $0.97 \mathrm{~mm} \mathrm{~min}^{-1}$. In the first 16 minutes $59.2 \mathrm{~mm}$ of rainfall was measured. Mean intensity at that time was almost $4 \mathrm{~mm} \mathrm{~min}^{-1}$, the highest intensity was measured within the first 5 minutes with $29.6 \mathrm{~mm}$ of precipitation with mean intensity of almost $6 \mathrm{~mm}$ $\min ^{-1}$.

The downpour caused intensive runoff on the field with sugar beet, which covered $12 \%$ of an arable land in 2006 . On a 0.5 ha plot, all the plant seedlings were washed away together with the eroded soil. On the remaining fields with sugar beets, the crops were silted up and consequently the yields were reduced.
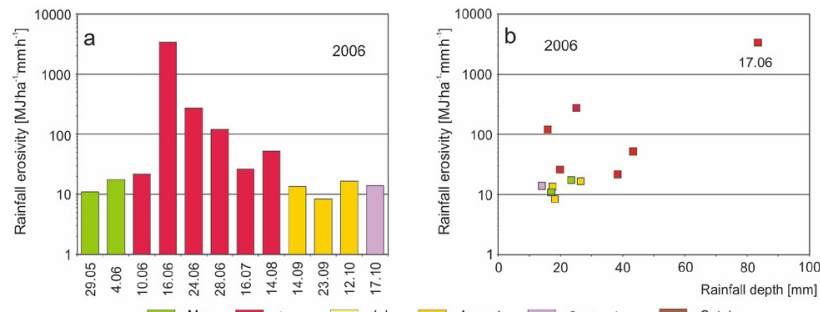

May June $\square$ Juy
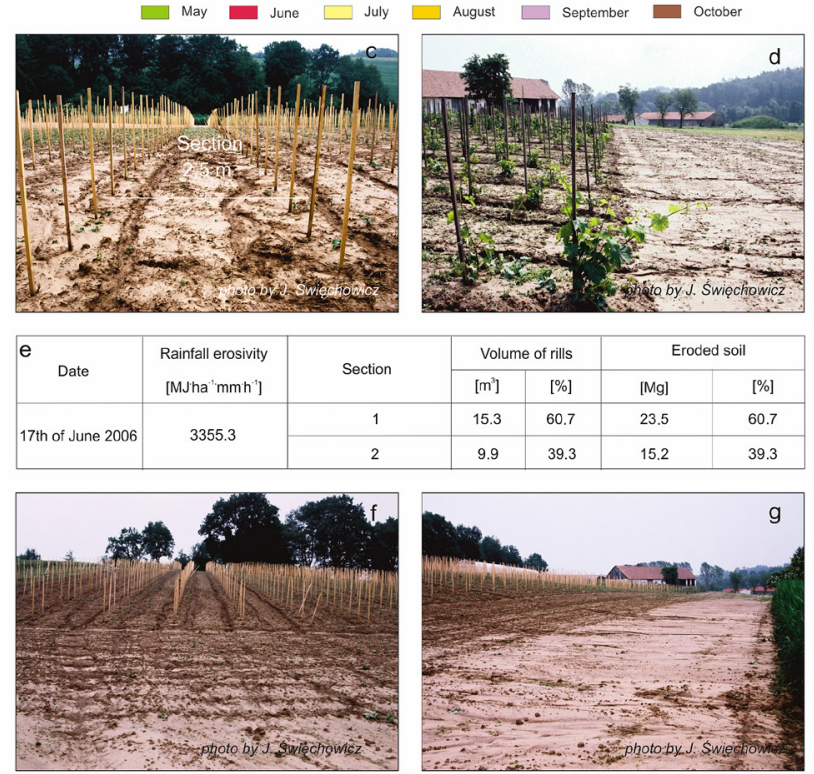

Fig. 8. Results of downpour on 17 June, 2006 (Eazy near Bochnia)

a - rainfall erosivity from May to October 2006, b - rainfall erosivity as a function of its amount, c-d - pattern of rills in the vineyard, e - volume of rills and total amount of eroded soil, $\mathrm{f}-\mathrm{g}-$ at the foot of the slope 
On the land with cereals, there was intensive surface flow too. Ephemeral gully was form in the axis of the sub-catchments along the natural drainage line. Soil erosion was strong only along the episodic channel and sediments were accumulated in form of wide and broad deluvial fan in the outlet of the gully. On the remaining area soil erosion was not intensive because of dense vegetation cover. The results of the extreme rainfall were most visible on the grapevine field (Fig. 8 ). The vineyard was established in spring 2005 on the area of 0.3 ha. In spring (May) 2006 grapevines were planted on additional 0.7 ha. Thus in June, when the rainfall took place, 0.7 ha of the vineyard was devoid of vegetation cover. Between the rows of grapevine (which were $2.5 \mathrm{~m}$ apart), an intensive surface flow took place in several sections. Along the rows of grapevine rills formed which were typically several to over ten $\mathrm{cm}$ deep. The eroded material was accumulated in the footslope deluvial plain above the edge that separated it from the valley bottom (Fig. 8).

\section{Discussion}

The obtained results refer to the Wiśnicz Foothills (Brzesko Foreland) marginal zone covered with loess like formation with Stagnic Luvisols. The soils are very susceptible to soil erosion. Mean annual soil erodibility factor ( $\mathrm{K}$ factor) reached the value of $0.0377 \mathrm{Mg}$ ha h MJ ${ }^{-1} \mathrm{~mm}^{-1} \mathrm{ha}^{-1}$ in 2007 that was significantly lower than the value calculated based on the USLE model (0.0738). In 2009 mean annual value of $\mathrm{K}$ factor was $0.0914 \mathrm{Mg}$ ha h MJ ${ }^{-1} \mathrm{~mm}^{-1} \mathrm{ha}^{-1}$ that was not much below the value calculated according to USLE (Święchowicz 2012a, 2016).

According to Hess (1965) classification, the Carpathian Foothills belongs to temperate warm climatic vertical zone. The climate of the Carpathians is characterized by the variability of its parameters caused by the growing height of the mountain belts from the north to the south as well as by the considerable latitudinal extent of the mountain range. The summer season is crucial to annual precipitation totals. Maximum daily precipitation totals are the result of intense continuous rainfall (mainly in June and July) and short local downpours (mainly in May).

The research period covered three contrasting years, one dry (2008) and two wet (2007 and 2009). Monthly totals of precipitation varied a lot. Total of 212 potential erosive rainfall events occurred during summer periods in 1987-2009, based on USLE criteria. A mean of 67.8 days with precipitation were recorded in the six summer months, with only 9.2 days featuring potentially erosive rainfall. A simplification of the above statement might be that erosive rainfall usually occurs once every seven rainfall days. During
93\% (2007), 100\% (2008) and 95\% (2009) of days in summer half years the slope are stable because rainfalls do not occur or are too small to initiate soil erosion by water. The value of the 90th percentile was $200 \mathrm{MJ} \mathrm{mm} \mathrm{ha}{ }^{-1} \mathrm{~h}^{-1}$. Hence, an $E I_{30}$ value of $>200 \mathrm{MJ}$ $\mathrm{mm} \mathrm{ha} \mathrm{h}^{-1} \mathrm{~h}^{-1}$ may be considered extreme for the edge of the Wiśnicz Foothills. Only 19 extreme rainfall events were found for the study period, which translates into 0.8 events per year. The value of $E I_{30}$ for the six months of summer ranged from 67.0 in 2003 to 3,929.4 MJ mm ha ${ }^{-1} \mathrm{~h}^{-1}$ in 2006.

Research into splash, which was conducted in the summer half-year in hydrological years 2007-2009 on an experimental plot show thet the raindrop erosion, took place after evry single rainfall. This suggests that the sediment transport occurs during virtually every type of rainfall event. While the mass of the material carried varies, the highest energy rainfall does e frequency of rainfall events: the more rainfall events, the more sediment is carried down slope. Every rainfall event with the potential to cause erosion in the period 1987-2009 caused splashing. The threshold values for splash erosion were the lowest values for actual rainfall events: $E I_{30}$ $-2.3 \mathrm{MJ} \mathrm{mm} \mathrm{ha}^{-1} \mathrm{~h}^{-1}$ and $I_{30}-1.6 \mathrm{~mm} \mathrm{~h}^{-1}$ (Fig. 4b). While every rainfall event during the study period caused splashing, the ability to cause erosion varied. The mass of the material transported alond the slope is large, but transport takes place at short distances $(2-48 \mathrm{~cm})$. The role of raindrop erosion in the formation of new forms and the transformation of existing ones is not big (Święchowicz 2012a).

Unlike splash erosion, surface runoff and slope wash did not occur during every recorded rainfall event. Only sporadic short-duration and high intensity rainfall events may trigger severe soil erosion causing serious loss of topsoil. On agricultural slopes soil erosion by water in the summer half-year may not occur at all, if the year is characterized by a low total rainfall, and single rainfall erosivity is too small to cause erosion when the area is cover with plants. This situation occurred in dry 2008, when two rains with erosivity of slightly over $80 \mathrm{MJ} \mathrm{mm} \mathrm{ha} \mathrm{m} \mathrm{h}^{-1}$, did not cause soil erosion - even on fallow plot, completely in vegetation season devoid of protection of plant cover. In contrast, in wet 2007 , seven rains with low erosivity (from 3.8 to $41.3 \mathrm{MJ} \mathrm{mm} \mathrm{ha}^{-1} \mathrm{~h}^{-1}$ ) escaped from a fallow plot near $18 \%$, and from a potatoes plot slightly over $10 \%$ of the soil eroded in the summerhalf year (Święchowicz 2010a, 2012a, 2017).

Soil erosion rarely took place on all the fields simultaneously and its intensity is differentiated along the longitudinal profile of the slope. In the transformation of slopes, a greater role is played by land use, the area of crops and how big the crops are during the rainfall rather than by the parameters of rainfall. Soil resistance to erosion depends on the type of crops 
and spatial crop structure. Identical rainfall (same amount, intensity and duration) causes different soil loss depending on land use. Mean annual soil loss in 2007-2009 amounted to $63.6 \mathrm{~kg} \mathrm{ha}^{-1}$ for winter wheat, $26.7 \mathrm{~kg} \mathrm{ha}^{-1}$ for meadow, $43,396.0 \mathrm{~kg} \mathrm{ha}^{-1}$ for potato, $22,463.7$ for sugar beet and $72,949.6 \mathrm{~kg} \mathrm{ha}^{-1}$ for fallow.

When water is channelled across unprotected land and washes away the soil, ephemeral gullies are formed along the drainage lines. Linear erosion did not occur during every slope wash event.

In the Wiśnicz Foothills on arable slopes, soil erosion by water has high intensity (Święchowicz 2008a, 2009, 2010a, 2012a). Even there the number of events during the year is varied because it is often conditioned by the lack of dense vegetation in many crops cover in many crops during a vegetation period, as well as by rainfalls that trigger erosion (Gil 1999, Święchowicz 2012a).

Soil erosion by water change shape and length of the slopes: decrease inclination, extending the footslope area, creating footslope plains, extending the bottom of the valleys (Święchowicz 2004, 2008a, b, 2012a, 2017). Soil erosion by water also creates new forms: rills, ephemeral channels, ephemeral gullies, gullies (Święchowicz 2008a, 2010b, 2011, 2012a, 2017).

Change in the slope relief is brought about by short transformation periods, during which soil erosion by water takes place, especially by those with the biggest effectiveness and dynamics. Those periods which, depending on the criterion adopted, lasted from 0.3 to $5 \%$ of the time of study are the most interesting and effective episodes in the development of slopes in agricultural areas. Periods of stability and transformation of slopes are subject to dynamic season changes. Erosion by water becomes most dynamic during potentially erosive rains. Rainfall threshold values are different for particular types of processes; the lowest for splash, higher for slopewash, higher for linear erosion, and the highest for ephemeral gully erosion. Every potentially erosive rain initiated splash. More than a half of potentially erosive rains according to the USLE criterion did not trigger off slopewash. Linear erosion did no appear during all slopewash events and occurred only during potentially erosive rains. However, the number of instances of ephemeral gully erosion was much lower.

During many events, part of soil material is transported and locally deposited on slopes, and does not transform the slope morphology in any visible way. During some events, the material is only transported from the water divide to the foot of the slope and deposited there. Only during several events is the soil supplied directly to the stream channel.

Slopewash on slopes is less frequent than splash. The number of slopewash evens is usually lower than the number of potentially erosive rains. Linear erosion is even rarer than splash or slopewash. The differences between the probability of occurrence of slopewash and linear erosion are not very big (Święchowicz 2012a).

Soil erosion by water in Łazy, in the lowest marginal zone of the Wiśnicz Foothills, during the study period was characterized by a smaller intensity in comparison to Szymbark (northen part of the Bystrzanka catchment, situated on the border of Beskid Niski Mts and Ciężkowice Foothills) in 1969-2000. As for the potato crops, mean annual values of slope were slightly smaller (by 15\%), and the wheat crops were halved.

\section{Conclusions}

Soil erosion by water is a complex process determined by many factors of the natural environment. It occurs in various forms and intensity, which causes methodological difficulties in its research. Large variability and complexity of slope forms and processes makes their reaction to external factors different and development trends very diverse.

In the Wiśnicz Foothills change in the slope relief was brought about by short transformation periods (lasted from 0.3 to $4 \%$ of the time of study), during which soil erosion by water took place, especially if it was caused by events of high magnitude and low frequency. During the remaining period of the summer half-year, the slopes are stable, because rainfalls do not occur or are too small to initiate overland flow and slope wash.

Rainfall threshold values $\left(E I_{30}\right.$ or $\left.I_{30}\right)$ were different for particular types of processes; the lowest for splash, higher for slope wash, then for linear erosion (rill and the ephemeral gully erosion). Rainlall erosivity above 200 erosive units may be considered extreme for the edge of the Carpathian Foothills. Only 19 extreme rainfall events were found for the study period, which translates into 0.8 events per year.

Morphological effectiveness of rainfalls that initiate soil erosion is differentiated and depends mainly on type of plant cover and spatial crop pattern. The mosaic of fields, which are differently used, makes the soil loss large only if the slopes are ploughed and unprotected by a dense cover of vegetation.

In 1987-2009 most erosion events were associated with the transport of material over short distances. It was during some erosion events that transport occurred from the watershed down to the base of the hills. It was during just a few erosion events that soil material was transferred directly to the stream channel. Only incidental extreme rainfall leads to significant changes of the forms already present on 
the slope and to the formation of new ones, and the material transported down the slope is accumulated at the bottom on the footslope plains or in the valley bottom in the form of deluvial fans.

Deposition of the material at the bottom of the slope and in the valley bottom leads to the elevation and extension of the valley bottom and at the same time, it hinders transport of the solid material from the slope to the channel, and its supply is only local and episodic. In the Wiśnicz Foothill catchments, slope and channel are weakly linked. The connectivity between the two is local and episodic. Only during the most erosive rainfalls does sediment flux directly to the stream channel take place. Even then, most of the material is deposited at the footslope and in flat valley bottoms.

\section{Acknowledgements}

Thanks are due to Alicja Waligóra-Zblewska for preparing the English translation of the paper. This project is partially supported by the Polish State Committee for Scientific Research Grants (grant no 2P04E 053 30) and research grant no. NN 306 048334 .

\section{References}

Auzet A.V., Boiffin J., Papy F., Maucorps J., Ouvry J.F., 1990. An approach to the assessment of erosion forms and erosion risk on agricultural land in the northern Paris Basin, France. In: J.B.Boardman, I.D.L.Foster, J.A.Dearing (eds). Soil Erosion on Agricultural Land. Chichester (John Wiley \& Sons): 384-400.

Boardman J.B., 1995. Damage to property by runoff from agricultural land, South Downs, southern England, 1976-93. Geographical Journal 161: 177-191.

Brown L.C., Foster G.R., 1987. Storm erosivity using idealized intensity distributions. Transactions of the ASAE 30: 379-386.

Cerda A., Flanagan D.C., Le Bissonnais Y., Boardman J., 2009. Soil erosion and agriculture. Soil \& Tillage Research 106: 107-108.

Cerda A., Imeson A.C., Poesen J., 2007. Soil water erosion in rural areas. Catena (Special issue) 71: 191-252.

Clark E.H., Haverkamp J.A., Chapman W., 1985. Eroding Soils. The off-Farm Impacts. Washington D.C. (The Conservation Foundation).

Czyżowska E.,1995. Skutki geomorfologiczne i sedymentologiczne gwałtownej ulewy w dolinie Kalinki 15 września 1995 roku (Wyżyna Miechowska). Przegląd Geologiczny 44(8): 813-816.

Długosz M., Gębica P., 2008. Geomorfologiczne skutki oraz rola lokalnych ulew i powodzi w kształtowaniu rzeźby progu Pogórza Karpackiego (na przykładzie ulewy z czerwca 2006 r. w rejonie Sędziszowa Młp.). In: W.Florek (ed), Rola procesów ekstremalnych w kształtowaniu rzeźby. Landform Analysis 8: 13-20.

Garcia-Ruiz J.M., 2010. The effects of land uses on soil erosion in Spain: a review. Catena 81: 1-11.

Gerlach T., 1966. Współczesny rozwój stoków w dorzeczu górnego Grajcarka (Beskid Wysoki). Prace Geograficzne IG PAN 52.

Gerlach T., 1976a. Współczesny rozwój stoków w polskich Karpatach Fliszowych. Prace Geograficzne IGiPZ PAN 122

Gerlach T., 1976b. Bombardująca działalność kropel deszczu i jej znaczenie w przemieszczaniu gleby na stokach. Studia Geomorphologica Carpatho-Balcanica 10: 125-137.
Gil E., 1999. Obieg wody i spłukiwanie na fliszowych stokach użytkowanych rolniczo w latach 1980-1990. Zeszyty IGiPZ PAN 60: 1-78.

Gil E., 2009. Ekstremalne wartości spłukiwania gleby na stokach użytkowanych rolniczo w Karpatach Fliszowych. In: W.Bochenek, M.Kijowska (eds), Funkcjonowanie środowiska przyrodniczego w okresie przemian gospodarczych w Polsce. Biblioteka Monitoringu Środowiska, Szymbark: 191-218.

Hess M., 1965. Piętra klimatyczne w polskich Karpatach Zachodnich. Zeszyty Naukowe UJ, Prace Geograficzne 11: 1-267.

Jadczyszyn J., 2010. Spływ powierzchniowy i erozja gleby w użytkowanej rolniczo mikrozlewni stokowej (Rogalów, Wyżyna Lubelska). In: E.Smolska, J.Rodzik (eds), Procesy erozyjne na stokach użytkowanych rolniczo (metody badań, dynamika i skutki). Prace i Studia Geograficzne 45:67-77.

Janicki G., 2007, Rola zdarzeń katstrofalnych w funkcjonowaniu geosystemów uzytkowanych rolniczo. In: J.Szkutnicki, U.Kossowska-Cezak, E.Bogdanowicz, M.Ceran (eds), Cywilizacja i zywioły. Monografie Instytutu Meteorologii i Gospodarki Wodnej, Warszawa: 236-245.

Janicki G., 2016. System stoku zmywowego i jego modelowanie statystyczne - na przykładzie Wyżyn Lubelsko-Wołyńskich. Wydawnictwo UMCS, Lublin.

Janicki G., Kociuba W., Rodzik J., Zgłobicki W., 2010. Ekstremalne procesy geomorfologiczne we wschodniej części wyżyn polskich - warunki występowania i oddziaływanie na rzeźbę. In: E.Smolska, J.Rodzik (eds), Procesy erozyjne na stokach użytkowanych rolniczo (metody badań, dynamika i skutki). Prace i Studia Geograficzne 45: 11-28.

Janicki G., Zgłobicki W., 1998. Geomorfologiczne skutki ulewy (z 16 września 1995 r.) w okolicy Garbowa na Wyżynie Lubelskiej. Annales Universitatis Mariae Curie-Skłodowska, Sectio B 53(6): 109-129.

Józefaciuk A., Józefaciuk C., 1995. Erozja agroekosystemów. Biblioteka Monitoringu Środowiska, Warszawa.

Klimek M., 1995. Soil cover in the experimental drainage basin of Dworski Potok (Wieliczka Foothills). In: L.Kaszowski (ed), Struktura i funkcjonowanie środowiska przyrodniczego Progu Karpat. Zeszyty Naukowe UJ, Prace Geograficzne 100: 99-111.

Kostrzewski A., Klimczak R., Stach A., Zwoliński Z., 1989. Morphologic effect of heavy rainfall (24 May, 1983) over relief features of the scarpland in the middle Parsęta valley, West Pomerania, Poland. Quaestiones Geographicae, Special Issue 2: 101-110.

Kostrzewski A., Klimczak R., Stach A., Zwoliński Z., 1992. Wpływ procesów katastrofalnych na funkcjonowanie współczesnego systemu denudacyjnego obszarów młodoglacjalnych - Pomorze Zachodnie. Badania Fizjograficzne nad Polską Zachodnią 18A: 55-82.

Lach J., 1985. Transformacja rzeźby wywołana gospodarczą działalnością człowieka w dorzeczu Mleczki. Folia Geographica, Series Geographica-Physica 17: 121-139.

Majewski M., 2014. Wykorzystanie eksperymentu terenowego w badaniach erozji wodnej gleb w zlewni Chwalimskiego Potoku (Pojezierze Drawskie, górna Parsęta). Prace Geograficzne UJ 138: 57-66.

Novara A., Gristina L., Saladino S.S Santoro A., Cerda A., 2011. Soil erosion assessment on tillage and alternative soil managements in a Sicilian vineyard. Soil \& Tillage Research 117: 140-147.

Olecki Z., 1970. Cours et effects d'une violente averse le 29 mai 1968 a Gaik-Brzezowa. Studia Geomorphologica Carpatho-Balcanica 4: 101-105.

Rejman J., 2006. Wpływ erozji wodnej i uprawowej na przekształcenie gleb i stoków lessowych. Acta Agrophysica 136(3): 1-90.

Rejman J., Brodowski R., 2005. Rill characteristics and sediment transport as a function of slope length during a storm event on loess soil. Earth Surface Processes and Landforms 30: 231-239.

Rejman J., Brodowski R., 2010. Ocena erozji wodnej gleby lessowej na uprawach buraka cukrowego i pszenicy jarej na podstawie badań poletkowych. In: E.Smolska, J.Rodzik (eds), Procesy 
erozyjne na stokach użytkowanych rolniczo (metody badań, dynamika i skutki). Prace i Studia Geograficzne Uniwersytetu Warszawskiego 45: 215-228.

Rejman J., Michiels P., Cadron W., Gabriels D., Dębicki R., 1990. Splash detachment on a silt loam soil with and without a plant cover of triticale. Zeszyty Problemowe Postępów Nauk Rolniczych 388: 161-168.

Rejman J., Pawłowski M., Dębicki R., Link M., 1994. Stability of aggregates and erodibility of loess Soils. Polish Journal of Soil Science 27(2): 87-91.

Rejman J., Rodzik J., 2006. Poland, In: J.B.Boardman, J.Poesen (eds), Soil Erosion in Europe. John Wiley \& Sons Ltd., Chichester: 95-106.

Rejman J., Usowicz B., 2002. Evaluation of soil loss contribution areas on loess soils in southeast Poland. Earth Surface Processes and Landforms 27: 1415-1424.

Reniger A., 1950. Próba oceny nasilenia i zasięgów potencjalnej erozji gleb w Polsce. Roczniki Nauk Rolniczych 54(1): 1-59.

Reniger A., 1955. Soil erosion in the Carpathian Mountains within the watershed of the stream Łukowica. Roczniki Nauk Rolniczych 71(F) 1: 149-210.

Reniger A., 1957. Ilość materiału unoszonego ze zlewni podgórskiej rzeki Mleczki. Gospodarka Wodna 7: 344-347.

Rodzik J., 2001. Wpływ rozczłonkowania stoku na zróżnicowanie erozji gleb uprawnych. Folia Universitas Agriculture Stetinensis, Agricultura 217(87): 201-204.

Rodzik J., Janicki G., 2003. Local downpours and their erosional effects. Papers on Global Change IGBP 10: 49-66.

Rodzik J., Janicki G., Zagórski P., Zgłobicki W., 1998. Deszcze nawalne na Wyżynie Lubelskiej i ich wpływ na rzeźbę obszarów lessowych. Dokumentacja Geograficzna 11: 45-68.

Smolska E., 2003. Erozja powierzchniowa gleb na Pojezierzu Suwalskim i niektóre jej uwarunkowania klimatyczno-topograficzne. Przegląd Naukowy Inżynieria i Kształtowanie Środowiska, Wydawnictwa SGGW Warszawa: 12 1(26): 12-23.

Smolska E., 2005. Znaczenie spłukiwania w modelowaniu stoków młodoglacjalnych na przykładzie Pojezierza Suwalskiego). Wydział Geografii i Studiów Regionalnych UW, Warszawa.

Smolska E., 2008. Rola opadów ekstremalnych w denudacji stoków młodoglacjalnych na przykładzie Pojezierza Suwalskiego. In: W.Florek (ed), Rola procesów ekstremalnych w kształtowaniu Rzeźby. Landform Analysis 8: 69-72.

Smolska E., 2010. Spływ wody i erozja gleby na piaszczystym stoku w obszarze młodoglacjalnym - pomiary poletkowe (Pojezierze Suwalskie, Polska NE). In: E.Smolska, J.Rodzik (eds), Procesy erozyjne na stokach użytkowanych rolniczo (metody badań, dynamika i skutki). Prace i Studia Geograficzne Uniwersytetu Warszawskiego 45: 197-214.

Stankoviansky M., 2002. Bahenné povodne - hrozba úvalín a suchých dolín. Geomorphologia Slovaca 2: 5-15.

Stępniewski K., Demczuk P., Rodzik J., Siwek K., 2010. Związki między opadem deszczu, a spływem powierzchniowym i spłukiwaniem gleby na poletkach doświadczalnych o różnym użytkowaniu (Guciów - Roztocze Środkowe). In: E.Smolska, J. Rodzik (eds), Procesy erozyjne na stokach użytkowanych rolniczo (metody badań, dynamika i skutki). Prace i Studia Geograficzne Uniwersytetu Warszawskiego 45: 229-241.

Święchowicz J., 2002a. The influence of plant cover and land use on slope-channel decoupling in a foothill catchment: A case study from the Carpathian Foothills, southern Poland. Earth Surface Processes and Landform 27: 463-479.

Święchowicz J., 2002b. Linkage of slope and fluvial processes in sediment and solute export from a foothill catchment in the Carpathian Foothills of south Poland. Earth Surface, Processes and Landforms 27(12): 1389-1413.

Święchowicz J., 2004. Role of extreme processes in slope transformation in the Carpathian Foothills). In: B.Izmaiłow (ed.), Przyroda - Człowiek - Bóg. Instytut Geografii i Gospodarki Przestrzennej UJ, Kraków: 83-91.
Święchowicz J., 2008a. Soil erosion on cultivated foothill slopes during extreme rainfall events in the Wiśnicz Foothills of southern Poland. Folia Geographica, series Geographica Physica 39: 80-93.

Święchowicz J., 2008b. Wpływ spłukiwania, sufozji i procesów eolicznych na współczesną ewolucję stoków Karpat fliszowych. In: L.Starkel, A.Kotarba, A.Kostrzewski, K.Krzemień (eds), Współczesne przemiany rzeźby Polski, Instytut Geografii i Gospodarki Przestrzennej UJ, Kraków: 80-94.

Święchowicz J., 2009. Geomorphic and economic effects of heavy rainfall of 17 June 2006 at the Jagiellonian University's farmland in Łazy (Wiśnicz Foothill). In: W.Bochenek, M.Kijowska (eds), The operation of the natural environment during economic transformatons in Poland, Biblioteka Monitoringu Środowiska, Szymbark: 219-230.

Święchowicz J., 2010a. Ekstremalne spłukiwanie i erozja linijna na stokach użytkowanych rolniczo w polskich Karpatach fliszowych. In: E.Smolska, J.Rodzik (eds), Procesy erozyjne na stokach użytkowanych rolniczo (metody badań, dynamika i skutki). Prace i Studia Geograficzne Uniwersytetu Warszawskiego 45: 29-48.

Święchowicz J., 2010b. Spłukiwanie gleby na użytkowanych rolniczo stokach pogórskich w latach hydrologicznych 2007-2008. In E.Smolska, J.Rodzik (eds), Procesy erozyjne na stokach użytkowanych rolniczo (metody badań, dynamika i skutki). Prace i Studia Geograficzne Uniwersytetu Warszawskiego 45: 243-263.

Święchowicz J., 2012a. Wartości progowe parametrów opadów deszczu inicjujących procesy erozyjne w zlewniach użytkowanych rolniczo. Uniwersytet Jagielloński, Instytut Geografii i Gospodarki Przestrzenne, Kraków.

Święchowicz J., 2012b. Water erosion on agricultural foothill slopes (Carpathian Foothills, Poland). Zeitschrift für Geomorphologie 56 (Suppl.) 3: 21-35.

Święchowicz J., 2016. Podatność na erozję wodną gleb wytworzonych z pyłowych utworów lessopodobnych (Przedgórze Brzeskie, Polska południowa). In: J.Święchowicz, A.Michno (ed), Wybrane zagadnienia geomorfologii eolicznej. Monografia dedykowana dr hab. Bogdanie Izmaiłow w 44. rocznicę pracy naukowej, Instytut Geografii i Gospodarki Przestrzennej UJ, Kraków: 331-366.

Święchowicz J., 2017. Assessment of natural and anthropogenic conditions for soil erosion by water in agricultural catchment in Poland. Geographia Cassoviensis 11(1): 89-105.

Święchowicz J., Michno A., 2005. Obszar badań. In: M.Żelazny (ed.), Dynamika związków biogennychw wodach opadowych, powierzchniowych i podziemnych w zlewniach o różnym użytkowaniuna Pogórzu Wiśnickim. Instytut Geografii i Gospodarki Przestrzennej UJ, Kraków: 29-42.

Szewrański S., 2009. Rozbryzg jako forma erozji wodnej gleb lessowych. Wydawnictwo Uniwersytetu Przyrodniczego, Wrocław.

Szpikowski J., 2001. Wzajemne relacje rozbryzgu i spłukiwania jako przejaw zmienności erozji wodnej gleb na stokach o zróżnicowanym użytkowaniu rolniczym (Zlewnia Chwalimskiego Potoku, Górna Parsęta). Folia Universitatis Agriculturae Stetinensis 217(87): 221-226.

Szpikowski J., 2010. Uwarunkowania i wielkość rozbryzgu gleby na podstawie pomiarów na powierzchniach testowych w zlewni Chwailimskiego Potoku. In: E.Smolska, J.Rodzik (eds). Procesy erozyjne na stokach użytkowanych rolniczo (metody badań, dynamika i skutki). Prace i Studia Geograficzne Uniwersytetu Warszawskiego 45: 181-196.

Teisseyre AK., 1994, Spływ stokowy i współczesne osady deluwialne w lessowym rejonie Henrykowa na Dolnym Śląsku. Acta Universitatis Wratislaviensis. Prace Geologiczno-Mineralogiczne 43:1-218.

Wischmeier W.H., Smith D.D., 1978. Predicting rainfall erosion losses - a guide to conservation planning. Agricultural Handbook 537.

Zgłobicki W., 2002. Dynamika współczesnych procesów denudacyjnych w północno-zachodniej części Wyżyny Lubelskiej. Wydawnictwo UMCS, Lublin. 